\title{
Royendo palabras
}

\section{Editorial}

\section{Carlos Barberá Pastor}

Universidad de Alicante, España

carlos.barbera@gcloud.ua.es

https://orcid.org/0000-0003-3401-3670

\section{Para citar este artículo / To cite this article:}

BARBERÁ, C. Royendo palabras. En:[i2] Investigación e Innovación en Arquitectura y Territorio[en línea]. 2020, Vol. 8, Núm. 2. ISSN: 2341-0515. https://doi.org/10.14198/i2.2020.2.01

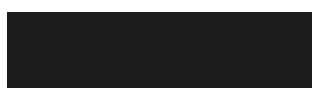


Pier Paolo Pasolini, en un artículo titulado La segunda era glaciar, escrito para l'Europeo, alude a dos sueños. Uno, podríamos decir, es real. Ocurrió en su mente mientras dormía en su cama. El otro es imaginario. Es uno de esos sueños alentadores en el que uno no pierde la esperanza de llegar a cumplir, aunque realmente sabe que no hay posibilidad de llevarlo a cabo. Lo contó en un «debate» a un grupo de obreros. El real, por como lo describe, tiene una doble certidumbre. Pasolini cuenta que estaba atado a la cama, en una infrecuente situación de soñar sobre el mismo espacio en el que uno se encuentra. Se hallaba rodeado del lenguaje, que ocupaba y se removía en toda la estancia. Debía ser parecido a esa capacidad abstracta del cerebro para quedar inmerso en el significado de las cosas, como si el espacio fuera capaz de transmitir por ósmosis el sentido de una lectura o un escrito. Esos vocablos tenían que ver con el poema que él mismo había redactado. A través de las letras que inundaban el recinto intentaba inútilmente explicar, a unos roedores, el valor de lo escrito sobre un papiro ubicado en la misma habitación. Pier Paolo Pasolini, según dice, "intentaba, con mi lenguaje, hacerme entender, explicarles el valor de mi poema. Nada. Yo estaba atado y nuestros lenguajes se aplicaban a significados diversos." Cuando despertó encontró totalmente roído el poema transcrito sobre un pergamino.

Uno trata de imaginar la situación de encontrar destrozadas las palabras cargadas de expresividad y significado. Cómo el cuidado de las estrofas expresadas en un material áspero y precioso de un papiro quedaba en nada, totalmente mordisqueado por los ratones que, royendo, alertaron en el sueño al poeta. La pesadilla se diferencia de cualquier otra por justamente la veracidad del acontecimiento. No es una imaginaria fantasía a la que la somnolencia es capaz de trasladarnos a otro lugar. El conjunto y estructura del sueño alertaban de una realidad sobre la que nada podía hacerse. Sin embargo, Pasolini, contándolo a un grupo de obreros, hizo de tal desgracia una situación poética por el carácter que pudo adoptar la habitación llena de palabras junto al sonido de los roedores mordisqueando el papel, reuniendo en el espacio vocablos, el sonido del roído y el intento por dar a entender el sentido de un poema que se desvanece.

No es de extrañar que Pier Paolo Pasolini tuviera sueños de esta índole. Era un ser perseguido por la derecha católica y el propio estado italiano. Debido a los principios comunistas del escritor, poeta, y director de cine, no se admitía su existencia, teniendo que enfrentarse a todo tipo de presiones jurídicas, censuras, e imputaciones falsas que lo relegaron a la soledad. La doble certidumbre de su sueño, en el que tras intentar darse a entender tratando de explicarse mediante el lenguaje para acabar en entendimientos kafkianos, ha sido el sino de su vida. Esa certeza de unos ratones destrozando su delicado trabajo, de algún modo, alude a la veracidad del papel censor de la iglesia y el estado que trataban de quitarle de en medio para sencillamente no ser coartados en sus quehaceres de enriquecimiento y lucro, el de mandatarios de estado con el que ejercer el poder de corrupción y especulación que el mismo Pasolini denunció hasta que fue asesinado.

Esta utilización del poder para acabar con cualquier intencionalidad ligada a la expresión poética ha sido el medio, como bien sabemos, para que el desarrollo del conocimiento 
no ponga en juego las artimañas que ha utilizado en toda su historia la opresión económica, política, monárquica, eclesial o institucional. Esa obsesión de mantener las supremacías sin que puedan ser puestas en cuestión a través de la difusión de las ideas, demonizando a grupos para que no alcancen un estatus, es y ha sido uno de los objetivos para silenciar cualquier amenaza de desestabilización de la corruptela. Hoy en día, con el auge de los partidos políticos de la extrema derecha parece que estén reapareciendo estas situaciones que tratan de evitar la puesta en valor de nuevos razonamientos, con el intento de acabar con la cultura y el trabajo del conocimiento. Sin embargo, este escenario no ha dejado nunca de darse.

En la institución universitaria y en la disciplina arquitectónica, por el carácter intelectual que las envuelven, es donde siempre se han ocultado acontecimientos que sellan nuevas maneras de funcionar. Lo hacen como si tuvieran un carácter estético, generando numerosos trabajos eruditos que son publicados o valorados mediante tratos de favor. Que no se muestren de forma visible las artimañas que gran parte de las personas que escalan puestos a costa de desmerecer la poética, es el medio que va de la mano de quienes tratan de posicionarse imponiendo sus líneas de pensamiento por el simple hecho de acaparar esa manera de estar en el mundo. Uno de los arquitectos que mejor ha presentado esta situación de invisibilidad en el espacio académico ha sido John Hejduk, justamente a través de la poética. Dice el arquitecto del Bronx:

\section{Como si el corazón estuviera aprisionado en una pizarra y un trozo de tiza arañara su superficie. Los copos blancos desintegrados se mezclaban con la sangre.}

El segundo sueño de Pier Paolo Pasolini, en referencia a gran parte de la población italiana, lo refiere a que estaban "más interesados por la literatura que por los concursos de la tele, empezaron a leer libros de estética, de poesía y de literatura, y lo devoraron todo, incluso los artículos de polémica literaria; hicieron grupos por las calles y los bares, escuchando a poetas recitar sus propios versos.”

Un sueño, en el ámbito de una revista de arquitectura, es que esto pudiera darse entre un reducido grupo de arquitectos, investigadores e intelectuales. 